\title{
INSURANCE LAW AND THE PRINCIPLE OF INDEMNITY IN LIGHT OF RIDGECREST NZ LTD V IAG NEW ZEALAND LTD
}

\section{Kasia Ginders*}

When the Supreme Court discussed the principle of indemnity in Ridgecrest NZ Ltd v IAG New Zealand Ltd, it was referred to as "awkward" in the context of a replacement policy. The application of the indemnity principle in the case raises further questions about the nature of the principle in insurance contracts. It is submitted that the indemnity principle is currently enforceable not as a legal test nor as a policy-based presumption; rather, it is applicable mostly because it is presumed the parties intended it to apply. This conclusion draws on both consideration of the rationales and rules of, exceptions to, and law reform concerning the principle. It also draws on analysis of the principle in light of Ridgecrest and two other recent cases following the Christchurch earthquakes that deal with the principle of indemnity.

\section{INTRODUCTION}

The principle of indemnity in insurance law holds that an insured is entitled to receive a full indemnity for his or her loss, no more and no less. However, Ridgecrest NZ Ltd v IAG New Zealand Ltd (Ridgecrest), a 2014 case in the New Zealand Supreme Court, has brought the nature of the principle into question. When an insured building owned by Ridgecrest NZ Ltd (Ridgecrest) sustained damage in successive Canterbury earthquakes, the Supreme Court held that Ridgecrest could claim up to the full amount of the sum insured per happening, despite being underinsured and not having repaired the damage from the earlier quakes when the insured building became a total loss. ${ }^{1}$ Ridgecrest could therefore obtain more than the amount they had insured for, a result that appears to

* Submitted as part of the LLB(Hons) programme at Victoria University of Wellington. I would like to thank my supervisor, Dr Bevan Marten, for his invaluable guidance and support.

1 Ridgecrest NZ Ltd $v$ IAG New Zealand Ltd [2014] NZSC 117, [2015] 1 NZLR 40 [Ridgecrest]. 
be somewhat at odds with the indemnity principle. This article explores the uncertainties surrounding the scope of the principle that arise in light of the decision in Ridgecrest.

Two other cases from 2014 dealing with the indemnity principle and Canterbury quake damage are also considered. The first is Tower Insurance Ltd v Skyward Aviation 2008 Ltd (Skyward), a Supreme Court decision that affirms the approach taken in Ridgecrest. ${ }^{2}$ Also discussed is the decision in QBE Insurance (International) Ltd $v$ Wild South Holdings Ltd (QBE Insurance), released a few weeks after Ridgecrest, in which the Court of Appeal clearly stated that the principle of indemnity survived Ridgecrest. ${ }^{3}$ Before these more recent cases are dealt with, this article evaluates the significance of three elements of the indemnity principle: the principle's underlying rationales, the rules the principle creates and supports, and the exceptions to the principle. Relevant law reform is also considered.

The question at the heart of this article is whether the principle of indemnity is truly a legal principle. Does it operate as a policy-based presumption that contracts must be interpreted consistently with, or is it simply descriptive of a particular type of contract? In other words, do courts have a discretion or perhaps an obligation to interpret contracts to be consistent with the principle, or is the concept of a no more and no less full indemnity merely applicable where it can be presumed the parties intended it to apply? It is argued that the latter appears more likely following Ridgecrest.

\section{INDEMNITY}

\section{A Various Meanings}

The word "indemnity" has several interlinked meanings in the insurance context. It may describe a type of policy, a measure of loss, or the so-called principle of indemnity. This article seeks to more accurately assess the scope of the third meaning. Courts may use the term indemnity without clearly distinguishing which meaning is intended, leading to some confusion. For clarity, the first two meanings mentioned are briefly explained below before discussion of the principle itself.

First, indemnity provides a distinction between contracts of indemnity, which provide cover for loss suffered, and contracts based on contingencies. "Loss suffered" in itself indicates the premise upon which the indemnity principle is based: loss is an essential element of indemnity insurance. ${ }^{4}$ Contingency contracts, in comparison, provide for a specified amount of money to be paid when an insured event occurs irrespective of loss suffered, for example, life insurance. ${ }^{5}$ The difference

2 Tower Insurance Ltd v Skyward Aviation 2008 Ltd [2014] NZSC 185, [2015] 1 NZLR 341 [Skyward].

3 QBE Insurance (International) Ltd v Wild South Holdings Ltd [2014] NZCA 447, [2015] 2 NZLR 24 [QBE Insurance], at [77]-[80].

4 Robert Merkin and Chris Nicoll (eds) Colinvaux's Law of Insurance in New Zealand (Thomson Reuters, Wellington, 2014) at 1.1.2(9)

5 See Gould v Curtis [1913] 3 KB 84 (CA) at 95 per Buckley LJ. 
lies principally in the fact that one cannot put a price on certain things, like loss of life, so the insurance received cannot be based on pecuniary loss. ${ }^{6}$ The indemnity principle, unsurprisingly, operates only in the context of indemnity policies.

Secondly, in the case of an insured event occurring under an indemnity contract, policies may offer different options for measuring the insurer's liability to cover the insured's loss. Indemnity value is one method. It involves measuring the loss caused by assessing the difference between the insured's position immediately before and after the event. This can be contrasted with replacement cover, where the amount required to indemnify the insured is calculated based on the cost of replacing or reinstating the thing insured, without making deductions for depreciation in value (or the increased cost of meeting new building standards in respect of property insurance).

\section{$B$ Scope of the Indemnity Principle: Options}

In the leading case of Castellain $v$ Preston, the indemnity principle was described as "fundamental" to insurance, ${ }^{7}$ but it is doubtful whether the modern scope and application of the principle supports such a statement. The scope of the indemnity principle, it is submitted, lies somewhere along a scale between a legal test as a high water-mark, and a measure of loss at the low water-mark. Four definitions are used in this article as points of reference to help determine where the principle fits on the scale.

\section{Legal test}

While the principle is said to be vital to insurance, there is little to suggest it constitutes a strict and compulsory legal test. It is not explicitly enshrined in statute, ${ }^{8}$ and there are several exceptions to the principle which clearly demonstrate that it is not compulsory. ${ }^{9}$ Few, if any, substantive arguments exist for affording the principle the status of a legal test. This article does not submit it as a possibility, but it is useful as a point of comparison for the other definitions.

\section{Policy-based presumption}

This option allows the principle greater scope to play a guiding role in the interpretation of contracts. Professor McGee seems to take this approach, stating that the principle is "properly regarded as a presumption rather than as a rule of law", and that the presumption may be rebutted by appropriate wording in a policy. ${ }^{10}$ The effort required to rebut such a presumption would reflect the

6 At 95

7 Castellain v Preston (1883) 11 QBD 380 (CA) at 386 per Brett LJ.

8 Although the Marine Insurance Act 1908 indirectly acknowledges the principle with provisions that conform to the requirements of the indemnity principle. See for example ss 33, 67 and 69.

9 See below at II C 3.

10 Andrew McGee The Modern Law of Insurance (3rd ed, LexisNexis Butterworths, London, 2011) at 4.17. 
policy arguments underlying the principle ${ }^{11}$ these arguments indicate the presumption should not be disregarded lightly.

\section{Presumed intention}

This more descriptive approach views the indemnity principle as something that acts to prevent the intentions of the parties being frustrated by presuming no more than a full indemnity was intended. Not carrying the same weight as a policy-based presumption, this option focuses more on the intentions of the parties than policy. It is accepted as the most likely option by Neil Campbell and Barnaby Stewart in their article "Prevention of Performance in Replacement Cost Insurance Preventing a Fictional Response". ${ }^{12}$ They state that the indemnity principle: ${ }^{13}$

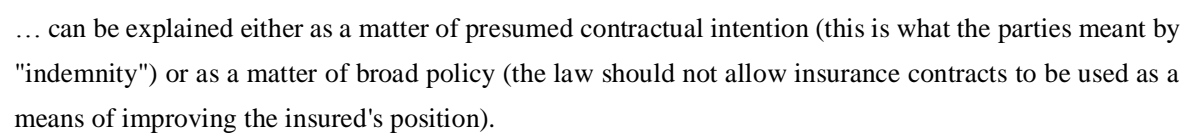

They go on to suggest that the former is more likely in Commonwealth countries. This reasoning is discussed in more detail below. ${ }^{14}$

\section{Business practice}

This option leaves the indemnity principle as merely descriptive of a common method of crafting insurance policies or measuring loss. It has the potential to carry more weight than just a measure of loss in that if clearly recognised as common business practice, the courts might choose to follow the principle when faced with ambiguity in a policy. ${ }^{15}$ However, the discussion in Ridgecrest on the indemnity principle suggests it has more legal substance than just a method of business practice.

These definitions are starting points, not clear cut options; it is submitted that the scope of the principle will lie somewhere between a policy-based presumption and a presumed intention approach.

\section{Evaluating the Scope of the Principle}

Analysis of several elements of the indemnity principle provides a framework for exploring its scope. This analysis is built upon when the judgments from Ridgecrest, Skyward and QBE Insurance are considered below. The elements are: the stated rationales that underlie the principle; the specific

11 See discussion of the arguments below at II C 1 .

12 Neil Campbell and Barnaby Stewart "Prevention of Performance in Replacement Cost Insurance - Preventing a Fictional Response" (2002) 10 Otago LR 229. See also Paul Michalik and Christopher Boys Insurance Claims in New Zealand (LexisNexis, Wellington, 2015) at 5.3, where a similar approach is taken.

13 At $n 3$.

14 See below at $I V A$.

15 See discussion in Firm PI 1 Ltd v Zurich Australian Insurance Ltd [2014] NZSC 147, [2015] 1 NZLR 432, at [77]-[79] and [88]-[93]. 
rules which the principle creates and supports; and the exceptions to the principle. A brief discussion of law reform concerning the principle is also included.

\section{Rationales}

The rationales of the indemnity principle are the key starting point. Understanding the rationales and their current relevance is necessary to assess the weight of the policies on which a principle that is more akin to a legal test or presumption might be based. The extent to which the rationales have become superfluous indicates the extent to which the scope of the principle should fall somewhere lower on the scale, towards mere business practice.

Three reasons are commonly given as justification for the principle of indemnity: avoiding windfalls to the insured, fraud prevention, and ensuring that the contract is not a wagering one.

(a) Avoiding windfall

Inherent in the notion that an insurance contract should provide no more and no less than a full indemnity is the goal of preventing windfalls to either party. This aspect is emphasised in Castellain $v$ Preston. Brett LJ declared that: ${ }^{16}$

The very foundation ... of every rule which has been applied to insurance law is this, namely, that the contract of insurance contained in a marine or fire policy is a contract of indemnity, and of indemnity only, and that this contract means that the assured, in case of a loss against which the policy has been made, shall be fully indemnified, but shall never be more than fully indemnified. That is the fundamental principle of insurance, and if ever a proposition is brought forward which is at variance with it ... that proposition must certainly be wrong.

The object of indemnity is simply to put the insured in the position they would have been in had the loss not occurred. ${ }^{17}$ The reason for this limitation was elaborated on by Lord Shaw in the 1921 case of British \& Foreign Insurance Co Ltd v Wilson Shipping Co Ltd. He warned against extending the indemnity principle in that it would lead to a situation "not in the region of indemnity against loss, but in the region of profit-earning". ${ }^{18}$

An example of a New Zealand case where the principle prevented unfair profit by the assured is the requirement in Guardian Royal Exchange Assurance of New Zealand Ltd v Roberts (Guardian) that the insured account for any amount received that exceeded her personal liability for the property insured. ${ }^{19}$ The respondent, Roberts, hired a car from Hertz for 16 days under a contract limiting her

16 Castellain v Preston, above n 7, at 386 per Brett LJ.

17 Malcolm Clarke Policies and Perceptions of Insurance Law in the Twenty-First Century (Oxford University Press, Oxford, 200) at 220.

18 British \& Foreign Insurance Co Ltd v Wilson Shipping Co Ltd [1921] 1 AC 188 (HL), at 207.

19 Guardian Royal Exchange Assurance of New Zealand Ltd v Roberts [1991] 2 NZLR 106 (HC). 
liability for damage to the car to $\$ 100$. Roberts entered into an insurance contract with the appellant for damage caused to the vehicle. The car suffered $\$ 6775.20$ of damage during the hire period. The insurer sought to limit its liability to Roberts' personal liability to Hertz of $\$ 100$; it was argued this was the true indemnity value.

While the court noted that an insured who did not own property could insure to protect against the full amount of loss or damage, if so they would be required to account for the amount over and above their personal liability for the property to the true owner. ${ }^{20}$ This was therefore not "inconsistent with the overriding principle that insurance of goods is a contract of indemnity", ${ }^{21}$ as the insured herself could not profit from the loss.

However, one can argue that the indemnity principle is not necessary to prevent unfair profit from an insurance contract. In most insurance contracts, an interpretation which allowed an insured to profit from a loss would be obviously outside the contemplation of the contracting parties, and thus a court would not permit such an outcome regardless of the principle. Other contracts may take account of the possibility of profit, and have appropriate premiums that reflect this. For example, replacement policies, where premiums are calculated based on the possibility of more than an indemnity being received. ${ }^{22}$ Interpretation using ordinary contract principles that look to the intent of the parties can equally achieve the purpose of avoiding unfair profit. Under this approach, the principle becomes a kind of self-fulfilling prophecy; it applies mostly because the parties expect it to apply, and structure their contract accordingly.

However, it would be unfair for an insured to obtain more than a full indemnity if a third party were consequently detrimentally affected. For example, a bailee whose interest is limited but who insures for the full value of the item. To the extent that prevention of windfall acts to protect the interests of third parties like Hertz and also those of insurers in cases of subrogation, the principle is probably much more compulsory in nature. ${ }^{23}$ However, while the doctrine of subrogation seeks to vindicate the principle of indemnity, ${ }^{24}$ the principle itself is not necessary to prevent windfall. Subrogation may also be enforced through an equitable remedy to prevent unjust windfall, where not contractually arranged for. ${ }^{25}$ Further, Lord Reid in A Tomlinson (Hauliers) Ltd v Hepburn stated that

20 At 114

21 A Tomlinson (Hauliers) Ltd v Hepburn [1966] AC 451 (HL) at 422 per Lord Reid as cited in Guardian Royal Exchange Assurance of New Zealand Ltd v Roberts, above n 19, at 112.

22 John Lowry and Philip Rawlings Insurance Law: Doctrines and Principles (3rd ed, Hart Publishing, Oxford, 2011) at 265 .

23 In cases of marine insurance, statute makes the situation clear for marine insurance: insurers have an automatic right to subrogation under s 79 of the Marine Insurance Act 1908.

24 Lord Napier and Ettrick v Hunter [1993] AC 713 (HL) at 744. Although the doctrine may be somewhat unnecessary: almost all insurers will have subrogation clauses in their insurance policies.

25 Malcolm A Clarke (ed) The Law of Insurance Contracts (6th ed, Informa Law, London, 2009) at 1022-1025. 
an insured's accountability to a true owner (like Hertz) was that of a trustee, suggesting equity fulfils the same purpose as the principle in this type of situation. ${ }^{26}$

(b) Prevention of fraud

A more persuasive reason for not allowing an insured to profit is fraud prevention. If the insured stands to profit following a loss, the incentive to cause loss increases, and the motivation to take precautions to avoid loss or damage is diminished. The latter is more insidious as it is not in itself fraudulent. If claims increase (or insurers perceive that they have increased), eventually so will premiums, distorting the process of spreading risk through insurance, as honest people end up paying for those who are dishonest or deliberately careless. ${ }^{27}$

Lord Mansfield CJ notes in Godin v London Assurance Co that "the rule was calculated to prevent fraud; lest the temptation of gain should occasion unfair and wilful losses". ${ }^{28}$ However, this statement was made in 1758. The insurance market and commercial world has undoubtedly changed substantially since then, and new methods have been adopted to alleviate the threat of fraud. In fact, insurers are required under the Insurance (Prudential Supervision) Act 2010 (IPSA) to be subject to an appropriate risk management programme. ${ }^{29}$ The programme must describe the insurer's risk assessment process and procedures for identifying and managing risks to financial security, including insurance risks. ${ }^{30}$

One example of insurers adapting to change concerns the introduction of replacement value policies, which offer cover on a new-for-old basis. The insured is able to obtain cover for purchase of a new version of the insured subject matter, often allowing for receipt of more than a full indemnity, creating an increased moral hazard for insurers. ${ }^{31}$ Two steps are typically taken to manage the moral hazard associated with replacement cost insurance. ${ }^{32}$ The first is by placing limitations that ensure the proceeds of the policy will be spent on reinstating the property, and the second is requiring reinstatement to be implemented with reasonable dispatch. ${ }^{33}$

In one sense, the development of such protective mechanisms by insurers illustrates the value of the indemnity principle in preventing fraud when replacement value insurance is not offered. If the

26 A Tomlinson (Hauliers) Ltd v Hepburn, above n 21, at 422 per Lord Reid.

27 JP Van Niekerk "Fraudulent Insurance Claims" (2000) 12 SA Merc LJ 69 at 71. See also Clarke, above n 17, at $252-253$.

28 Godin v London Assurance Co (1758) 1 Burr 489, 97 ER 419 (KB) at 421 per Lord Mansfield CJ.

29 Insurance (Prudential Supervision) Act 2010, s 73(1)

30 Section $73(2)$.

31 Campbell and Stewart, above n 12, at 232.

32 At 232 .

33 At 232 . 
potential for profit justifies special measures to prevent wrongdoing, impliedly they are necessary to plug a gap normally filled by the indemnity principle. The Insurance Council of New Zealand's approach to indemnity further supports the argument that fraud prevention is still a relevant rationale; it states that if an insured were put in a "better position after an insurance claim there would be a financial incentive to make claims". ${ }^{34}$

However, there has not been the same resistance to the introduction of replacement value policies in Commonwealth jurisdictions as that which took place in the United States. This suggests that less importance is placed in New Zealand on the indemnity principle as a method of fraud prevention. In the United States, where the principle is considered a "matter of public policy", replacement value policies initially required legislative approval. ${ }^{35}$ In fact, at first replacement coverage was only offered where the moral risk was deemed low, for example for insuring public utilities, schools and large manufacturers. ${ }^{36}$ Campbell and Stewart argue that the freedom to contract out of the principle in Commonwealth jurisdictions means a presumed intention rationalisation of the principle is more likely. ${ }^{37}$

The development of self-regulation methods through IPSA and in response to the risks associated with replacement policies also supports the notion that the indemnity principle is now more appropriately deemed a default presumption of intention, and that parties have the freedom to make their own assessment of risk and contract accordingly. That is to say, the intention of the parties contracting is more critical to the interpretation of an insurance contract than the indemnity principle's role in fraud prevention. The requirements of IPSA indicate that insurers have the ability to manage the risk of fraud through other methods if they choose, ${ }^{38}$ and therefore the indemnity principle is not strictly necessary.

A counterargument is that these changes show that a presumption that the principle applies should be rebuttable only where the contract shows evidence of careful management of the risk of fraud. That is to say, the courts have allowed replacement policies and other policies which may allow a profit with little fuss only because they believe insurers have taken proper steps to address the risk. ${ }^{39}$ This

34 "Insurance Concepts" (13 June 2014) Insurance Council of New Zealand <www.icnz.org.nz>.

35 Campbell and Stewart, above n 12, at 231.

36 Leo Jordan "What Price Rebuilding? A Look at Replacement Cost Policies" (1990) 19 Brief 17 at 18.

37 Campbell and Stewart, above n 12, at n 7.

38 For example the widespread introduction of limiting policies to a sum insured following the Christchurch earthquakes, discussed below at $I V D$

39 However, see discussion of Skyward at III B below. The Supreme Court's description of Tower being "content" to manage the risks of a replacement value policy in its own way suggests that insurers have a level of autonomy incompatible with this interpretation. See Skyward, above n 2, at [26]-[28]. 
slightly more paternal approach aligns more closely with a policy-based conception of the principle, placing the need to discourage fraud above contractual intent.

(c) Wagering contracts

While an insurance contract usually only protects a pre-existing interest, a potential for profit would create a new interest in the outcome, encouraging entrance into the contract because of the chance for profit $-\mathrm{a}$ kind of wager. Both courts and commentators have raised concerns about this. In British Traders Insurance Co Ltd v Monson, the High Court of Australia declared that underlying the indemnity principle is "the law's policy not to allow gambling in the form of insurance", ${ }^{40}$ and Bowen LJ warned against insurance contracts becoming mere "speculation for gain" in Castellain $v$ Preston. ${ }^{41}$ McGee has also raised concerns about the extent to which a replacement value policy becomes a wagering one by allowing an insured to make a profit. ${ }^{42}$

However, while wagering contracts in insurance remain illegal under statute in other jurisdictions such as Australia and England, this rationale has little legal application in New Zealand today. The provision in the Insurance Law Reform Act 1985 prohibiting contracts by way of gaming or wagering ${ }^{43}$ was repealed by the Gambling Act $2003,{ }^{44}$ although they remain illegal in respect of marine insurance. ${ }^{45}$ This renders the third rationale largely irrelevant in New Zealand. Further, wagering insurance contracts are no longer the social problem that they were when they were first made illegal. ${ }^{46}$

\section{Rules}

It was made clear in Castellain v Preston, and is noted by John Lowry and Phillip Rawlings, that "the overriding requirement of indemnity can be seen to underlie the rules which operate in the event of an insured loss". ${ }^{47}$ These rules are evidence of how the indemnity principle applies in a more practical sense. Some of the rules have already been mentioned, for example the doctrine of subrogation. Other rules include (but are not limited to) the doctrine of merger and the distinction between the loss to the insured and rateable value.

40 British Traders Insurance Co Ltd v Monson (1964) 111 CLR 86 (HCA) at 94.

41 Castellain v Preston, above n 7, at 399 and 401.

42 McGee, above n 10, at 4.17.

43 Insurance Law Reform Act 1985, s 7(2)(b)

44 Gambling Act 2003, s 374.

45 Marine Insurance Act 1908, s 5.

46 Michalik and Boys, above n 12, at 5.2.

47 Lowry and Rawlings, above n 22, at 264. 
The doctrine of merger provides that where a partial loss is followed by a total loss, unfinished repair costs are subsumed in the costs payable for the total loss. It is primarily an issue in marine insurance, where further loss may occur before repairs are able to be completed. While it was deemed to also be applicable in non-marine insurance in Crystal Imports Ltd v Certain Underwriters at Lloyd's of London, ${ }^{48}$ the Supreme Court in Ridgecrest decided otherwise. However, the authors of Colinvaux's Law of Insurance in New Zealand (Colinvaux) raise some doubts about this analysis. ${ }^{49}$

Falcon Investments Corporation (NZ) Ltd v State Insurance General Manager is a case which demonstrates the distinction between indemnity against the loss to the insured rather than for the value of the subject matter. The insured purchased a house, intending to demolish it and replace it with flats. While this was being arranged, the house was leased and insured for fire damage. Not long after, the tenant caused damage to the house and three days after that, it was damaged beyond repair by fire. The judge determined that in the circumstances, the loss to the insured was distinguishable from the value of the house. The actual harm suffered was the loss of rent from the house for the 12 months it was to be let before demolition. Deducted from this was the cost of repairing the damage caused by the tenants and the saving made in demolition costs as a result of the fire. ${ }^{50}$ The rule applied in the case is an application of the principle: if the insured had received cover for the full value for the house when his intention was to demolish it, he would have profited from his loss.

These rules demonstrate the potential scope of the principle in influencing contract interpretation and show it is more than just business practice. However, they do not go so far as to establish it as being of mandatory application, as evidenced by the exceptions discussed below.

\section{Exceptions}

Despite Brett LJ's suggestion that any proposition contrary to the principle must be incorrect, ${ }^{51}$ it is now clear the principle can be contracted around or rebutted. Situations that are difficult to reconcile with the principle of indemnity include replacement value policies and valued policies. Parties may also agree to a sum insured that is less than the full value of the subject matter, thus preventing a full indemnity being obtained.

48 Crystal Imports Ltd v Certain Underwriters at Lloyd's of London [2013] NZHC 3513, (2013) 18 ANZ Insurance Cases 61-997.

49 See $I V B$ below.

50 Falcon Investments Corporation (NZ) Ltd v State Insurance General Manager [1975] 1 NZLR 520.

51 Castellain v Preston, above n 7, at 386 per Brett LJ. 
In a valued policy, the value of the property is agreed when forming the contract, which may be more or less than the true value of the property. ${ }^{52}$ In Irving $v$ Manning, Patteson J stated that: ${ }^{53}$

A policy of assurance is not a perfect contract of indemnity. It must be taken with this qualification, that

the parties may agree beforehand in estimating the value of the subject assured ....

The authors of Colinvaux suggest the law permits this on the understanding that the agreed amount, although not necessarily a perfect indemnity, can be regarded as such by reference to the terms of the contract. ${ }^{54}$ However, valued policies are not always easily distinguished from non-valued policies. The construction of the contract must make it clear what is intended. The use of the phrase "sum insured" in itself has been held to refer only to a maximum sum for liability. ${ }^{55}$

Young v Commercial Union General Insurance Company Ltd demonstrates the difficulty in rebutting the presumption that the indemnity principle applies. ${ }^{56}$ It considered the application of a policy insuring household contents and personal effects in respect of a sterling silver tea set that was stolen. The policy held that no more than 5 per cent of the total sum insured would be paid for any one item (with some exceptions) unless specified. The tea set was listed as a specified item, with a price beside it of $\$ 22,125$. A valuation was obtained and provided to the insurer to support this price.

The Court found that on proper construction of the policy the insurer was only required to indemnify the insured for the indemnity value of the tea set when stolen; in this case the cost of obtaining a comparable tea set at $\$ 6,000$. The Court concluded that the specifying of the value was only for the purpose of avoiding the 5 per cent limit, and the provision of the certificate of value was deemed solely to be intended to advise the insurer of its possible liability in order to calculate premiums. 57

The indemnity principle itself is not mentioned in the judgment, but its application is evident in the way that the policy is construed. The Court's decision shows a preference for measuring loss by indemnity value rather than by a value agreed upon, despite the insured being liable to pay premiums calculated based on the specified value of the tea set. The case signals a requirement of very clear wording to rebut a presumption that cover will be measured according to indemnity value, or actual loss. This could be read as a confirmation that the policy underlying the principle is paramount.

52 Merkin and Nicoll, above $\mathrm{n} 4$, at 8.2.1.

53 Irving v Manning (1847) I HL Cas 287 (QB) at 774-775 per Patteson J.

54 Merkin and Nicoll, above $\mathrm{n}$ 4, at 8.2.1.

55 Merkin and Nicoll, above $\mathrm{n}$ 4, at 8.2.1.

56 Young v Commercial Union General Insurance Company Ltd (1988) 5 ANZ Insurance Cases 60-875 (CA).

57 At 75,514 . 
However, it is probably still compatible with a simple assumption that the parties did not contemplate the receipt of more than an indemnity.

The position of replacement value policies in respect of the principle of indemnity is not clear. Lowry and Rawlings state firmly that such contracts do not accord with the notion of indemnity, ${ }^{58}$ but believe the principle is contractual in origin, and is therefore variable. ${ }^{59}$ Furthermore, there has been no real resistance in Commonwealth jurisdictions to the introduction of such policies, as discussed above and also noted by McGee. ${ }^{60}$ Lowry and Rawlings' justification for exceptions to the principle and the lack of resistance to replacement policies in the Commonwealth both point toward a conclusion the principle is really about the presumed contractual intention of the parties, and is not based on policy issues.

\section{Law Reform}

In 1985, the Insurance Law Reform Act was passed. Among other things, it removed the requirement for an insurable interest in non-marine insurance. ${ }^{61}$ The need to prove an insurable interest was deemed an "unnecessary technicality" by the Statutes Revision Committee, as in indemnity insurance one could only recover when loss was proved. ${ }^{62}$ The Rt Hon Geoffrey Palmer, as Minister of Justice, reiterated this sentiment during the second reading of the Bill when he noted that the change reflected "the fact that under an indemnity insurance policy an insured person can recover only the amount he has actually lost when property is destroyed or damaged". ${ }^{63}$ From this it seems likely that the New Zealand Parliament considers the principle to be one of broad policy, although the somewhat brief consideration of its relevance does not permit any firm conclusions.

\section{Conclusions}

The discussion above provides some evidence of how and why the principle works to ensure the plaintiff does not recover more than a full indemnity. It is clear there are exceptions to these rules that limit the scope of the principle. However, previous case law has demonstrated the need for strong wording to rebut a presumption that the indemnity principle applies, suggesting the principle is not to be taken lightly. It is certainly more than mere business practice, and appears to have been taken more seriously than as a matter of contractual intention in the past.

58 Lowry and Rawlings, above n 22, at 265.

59 Lowry and Rawlings, above n 22, at 265.

60 McGee, above n 10.

61 Insurance Law Reform Act 1985, s 7.

62 (12 June 1985) 463 NZPD 4766.

63 (13 June 1985) 463 NZPD 4873. 
The utilisation of underlying rationales in justifying these rules further strengthens the argument that the indemnity principle has, at least in the past, been considered a principle based strongly on policy, and one not easily displaced or rebutted. The necessity of the principle to achieve the purposes that supposedly underlie it is doubtful in a modern context, making a presumed intention approach more probable.

\section{THE CANTERBURY CASES}

On 4 September 2010, a 7.1 magnitude earthquake struck the Canterbury region. Several substantial aftershocks followed, including a 6.3 magnitude quake on 11 February 2011 that was even more devastating than the original quake. One hundred and eighty five lives were tragically lost, and the road to recovery has been a long one. The total cost of the earthquakes in private insurance claims is estimated at $\$ 17$ billion, ${ }^{64}$ and insurers had paid out almost $\$ 15$ billion in settling claims by May $2015 .{ }^{65}$ The earthquakes have shaken the New Zealand insurance industry. The challenges of reinsurance, ${ }^{66}$ costly open-ended replacement policies and numerous protracted disputes over claims (many remain unresolved) are among the issues faced. ${ }^{67}$ The cases discussed below arose within this context.

\section{$A$ Ridgecrest NZ Ltd v IAG New Zealand Ltd}

Ridgecrest had insured a building in Christchurch with IAG. The policy provided for a maximum coverage of $\$ 1,984,000$ "in respect of any one happening". 68 This cap was to be reset after each happening, and cover was either for the loss or damage or estimated cost of repairs or, where replacement cover had been agreed, the cost of restoration or replacement if the building was damaged beyond repair. ${ }^{69}$ The liability cap was much less than the actual value of the building, and this fact was clearly understood by both parties. ${ }^{70}$

During the currency of the policy, the building was damaged in the course of four earthquakes. After each of the first two earthquakes in 2010, IAG assessed the damage and commissioned repairs, but these were only partially completed when the February 2011 earthquake struck, after which all

64 "Four years on: Insurance and the Canterbury Earthquakes" (February 2015) Vero <www.vero.co.nz >.

65 "Rebuild Statistics: Insurers Settle \$15 billion Canterbury Claims" (11 May 2015) Insurance Council of New Zealand <www.icnz.org.nz>.

66 See Rob Merkin "The Christchurch Earthquakes Insurance and Reinsurance Issues" (2012) 12 Canta LR 119.

67 Bill Bennett "Christchurch Rebuild: Quakes force policy change" The New Zealand Herald (online ed, Auckland, 25 March 2014).

68 Ridgecrest, above n 1, at [7].

69 At [8].

70 At [13] and [61]. 
repair work stopped. There was a further aftershock in June 2011, by which point the building was damaged beyond repair. IAG contended the building was a total loss after the February earthquake. ${ }^{71}$

The issue for the Supreme Court was whether Ridgecrest was entitled to claim up to the liability limit in respect of each happening. Ridgecrest claimed for the full $\$ 1,984,000$ in respect of the destroying earthquake, and for all the losses caused by earlier earthquakes. IAG contended that it was only required to pay for repairs actually undertaken in addition to the sum for the final earthquake. The High Court and Court of Appeal had both found for IAG, although on different grounds. ${ }^{72}$

In discussing whether Ridgecrest's claim was precluded by the indemnity principle, the Supreme Court held that the principle was not engaged as the $\$ 1,984,000$ cap was not based on, and was mutually understood as being less than, the replacement value of the building. ${ }^{73}$ The Court stated that the indemnity principle was an "awkward" phrase in respect of replacement value policies. ${ }^{74}$

The Court found that the policy placed only three limits on the insured's rights: there could be no double counting; each happening gave rise to a separate claim subject to the specified limit; and the total of all claims could not exceed the replacement cost of the building. ${ }^{75}$ This final limitation was described as a result of the indemnity principle. ${ }^{76}$

The Court's reasoning in the decision focused on the wording of the policy. It construed the words "in respect of any one happening" as meaning cover was reinstated up to the limit after each event, the full amount being claimable even for damage not repaired and subsequently unrepairable. ${ }^{77}$ The claims were not able to be subsumed into the total loss claim for the final earthquake under the merger doctrine. However, it was determined that the unrepaired damage was to be assessed on an indemnity basis by diminution in value rather than by replacement costs. ${ }^{78}$

The Court then considered whether the claim limit of $\$ 1,984,000$ should be deemed the replacement value of the building under the terms of the policy. It was determined that an "approach based firmly on the policy wording as to the resetting of liability limits" was preferable. ${ }^{79}$ The policy

71 At [11].

72 Ridgecrest New Zealand Ltd v IAG New Zealand Ltd [2012] NZHC 2954, [2013] Lloyd's Rep IR 67; and Ridgecrest New Zealand Ltd v IAG New Zealand Ltd [2013] NZCA 291, [2013] 3 NZLR 618

73 Ridgecrest, above n 1, at [61]

74 At [54].

75 At [62].

76 At [54].

77 At [24]-[29]

78 At [50]-[52].

79 At [60]. 
in issue was then evaluated, with four factors leading the Court to decide the limit was not deemed to be replacement value. They were:

(a) IAG had not presented its case on that basis;

(b) It would result in the cap being applied to more than one happening, which would be inconsistent with the cap resetting;

(c) Full replacement value would have caused the previous liabilities to be subsumed because it would not simply discharge liability for IAG, it would also cover all of Ridgecrest's previous losses, but the $\$ 1,984,000$ was insufficient to do this; and

(d) It would treat the policy as if it were an agreed replacement value one set at $\$ 1,984,000$, when the policy was not structured at all like a valued policy and there was no indication in the policy of an intention to set an agreed value - it was mutually understood that the cap was not based on and was significantly less than the true replacement value of the building. ${ }^{80}$

\section{$B$ Tower Insurance Ltd v Skyward Aviation 2008 Ltd (Skyward)}

The Supreme Court decision in Skyward was released a few months after Ridgecrest. It both endorses some of the reasoning in Ridgecrest and provides an example of a situation where the principle appears applicable, although the Court did not discuss it in detail and it was not decisive of the case. ${ }^{81}$

A dispute arose between the parties as to what Tower was required to pay Skyward after Skyward's building was damaged beyond economic repair in the Christchurch earthquakes. Among other arguments, Tower contended that accepting Skyward's proposed measure of loss would be "contrary to settled principles of indemnity", because it would result in Skyward recovering approximately $\$ 1,100,000$ for a property that had a pre-earthquake value of approximately $\$ 492,000$, and was bought for just $\$ 450,000$ two years prior to the earthquakes. ${ }^{82}$ The Court found for Skyward, and this seems strange in light of the principle: Skyward essentially made a profit of just over $\$ 600,000$ from their loss. The Court did not address this aspect of Tower's argument in detail in its judgment, but it did make a few brief references to the principle.

First, the Court reiterated its comment in Ridgecrest that the principle was "awkward" in the context of a replacement policy, adding in a footnote that Ridgecrest demonstrated how the "applicability of the indemnity principle is subject to the wording of the policy under consideration". ${ }^{83}$ This latter statement would seem to be the one that most closely resembles the Court's approach in

\footnotetext{
80 At [61].

81 Skyward, above n 2, at [4]-[11].

82 At [11].

83 At n 12
} 
respect of the principle in the case: the focus was, as in Ridgecrest, on the meaning of the policy wording.

The Court also noted that replacement policies brought with them moral hazards, but described Tower as having been content to manage this with certain provisions in its policy. These included requiring reinstatement of the house and limiting replacement value recovery to reimbursement for expenditure actually incurred by the insured. ${ }^{84}$

\section{$C$ QBE Insurance (International) Ltd v Wild South Holdings Ltd (QBE Insurance)}

Coming out two weeks after Ridgecrest, QBE Insurance dealt with several preliminary issues from three consolidated High Court cases. All three involved policies with full replacement cover to a sum insured and annual aggregate with automatic reinstatement of cover after loss. In each case, insured commercial buildings had sustained damage in the September 2010, February 2011 and June 2011 earthquakes. The preliminary question relevant to this discussion was whether the marine insurance doctrine of merger applied to material damage policies.

The Court held that Ridgecrest confirmed that the doctrine of merger could not apply to nonmarine insurance policies. However, according to the Court this did not prevent the insurers from relying on the indemnity principle. ${ }^{85}$ This is interesting in light of the fact that the insurer, when arguing for the application of merger, stated that they were seeking to ensure the application of the principle of indemnity itself. ${ }^{86}$

But the Court declared that the concepts were not co-extensive, and that the principle of indemnity "survived" Ridgecrest,${ }^{87}$ stating that the principle "inheres in any contract of indemnity". ${ }^{88}$ The Court stated that under the principle, if the total cost of reinstatement was more than the sum insured but the damage from each separate event was less than the sum insured, the actual loss would still be recoverable. This was provided the total amount was also less than the replacement cost of the building. However, the insured could not claim more than was necessary to repair the combined damage after the final event, as this would likely be less than the notional cost of repair following each event. ${ }^{89}$

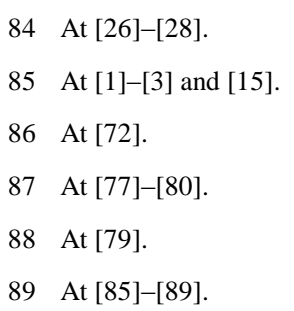


The Court's approach in combining repair costs, explicitly in line with the principle of indemnity, was meant to prevent the insureds profiting from their loss. The Court stated that recovering expenses that would not actually be incurred would allow the insured to "realise a profit from the policy, a result probably not intended in a contract of indemnity". 90

\section{THE ONGOING RELEVANCE OF THE PRINCIPLE}

It is submitted that Ridgecrest signals a change in the status and scope of the principle; that its socalled fundamental nature is less of a factor in the interpretation of policies than it purportedly was in 1883. This is especially so in New Zealand, a Commonwealth jurisdiction, and one where wagering policies are no longer illegal unless they fall into the much narrower category of gambling. It is further submitted that the status of the principle now falls somewhere closer to presumed intention, although an argument can still be raised for interpreting the principle as a policy-based presumption.

\section{A Presumed Intention or Broad Policy?}

The approach in Ridgecrest is very much based on the unusual wording of the policy. ${ }^{91}$ The crux of the decision was the interpretation of the words "for any one happening" and the understanding that the $\$ 1,985,000$ was never intended to equate to full replacement cover. In light of a result that may seem unsatisfactory for the insurer considering Ridgecrest was underinsured (and premiums would have been calculated accordingly), it does appear that the principle had a rather limited role to play in the case.

The comment in Skyward that the "applicability of the principle is subject to the wording of the policy under consideration" affirms a narrower interpretation of the principle. ${ }^{92}$ The statement can be interpreted in two ways. It can be read as merely meaning the principle creates a strong presumption that may be rebutted by clear wording in the policy. But more probably, it treats the principle as reflecting the presumed intention of the parties and therefore easily displaced by inconsistent wording in an insurance contract. Comments and discussion in Skyward and both QBE Insurance and Ridgecrest all support the latter interpretation as being more likely.

To begin with, Campbell and Stewart's paper is referenced in Skyward when the Supreme Court comments on the applicability of the principle, suggesting the Supreme Court does not disagree with the views espoused in the paper, namely that the principle applies as a matter of presumed intention. ${ }^{93}$ The Court of Appeal's emphasis in $Q B E$ Insurance on profit being "a result probably not intended" in

\footnotetext{
90 At [86].

91 Merkin and Nicoll, above n 4, at 519.

92 Skyward, above n 2, at n 12.

93 At n 12 .
} 
an indemnity contract, ${ }^{94}$ rather than declaring profit undesirable for substantial policy reasons also shows a focus on the intentions of the parties over policy.

The Supreme Court's comments in respect of double counting in Ridgecrest provide further support for a presumed intention status for the indemnity principle. The decision addresses how double counting is prevented by the principle of indemnity applying more broadly in respect of any separately identifiable building element first damaged and then later destroyed in successive events. ${ }^{95}$ When explaining the problem with double counting, however, the Court stated that "such a result would rationally be seen by insurers as unintended" as justification for suggesting "the courts should endeavour to avoid" it. ${ }^{96}$ The emphasis, instead of being based on a policy argument of preventing a profit to the insured, is again on interpreting the intentions of the parties.

\section{B Merger and Unsatisfactory Outcomes}

The authors of Colinvaux have compared the treatment of the principle in both Ridgecrest and $Q B E$ Insurance and found the former wanting. They disagree with the reasoning behind the nonapplication of merger in non-marine insurance, submitting that the doctrine should apply to both types unless ousted by agreement. ${ }^{97}$ They found the Court of Appeal's conclusions in QBE Insurance that indemnity could be applied although merger was foreclosed by Ridgecrest unconvincing: "merger is, after all, no more than an application of the indemnity principle in the limited situation where a partial and total loss occur in the same policy period". 98 They conclude the Court of Appeal's decision was in conflict with the Supreme Court on this point, and that the former's reasoning, being more compatible with the principle of indemnity, is preferable. ${ }^{99}$ It should be noted that Robert Merkin (an editor of Colinvaux), writing on behalf of DLA Piper New Zealand, states that the firm believes the judgment is restricted to policies mirroring four particular features of the one in Ridgecrest. ${ }^{100}$ However, the authors of Insurance Claims in New Zealand, Paul Michalik and Christopher Boys, believe it will apply more generally. ${ }^{101}$

While it is not possible to discuss the merger issue in depth here, one might draw the conclusion that the guaranteed application of the merger doctrine in marine insurance gives the principle the

$94 Q B E$ Insurance, above n 3, at [86].

95 Ridgecrest, above n 1, at [14] and [86].

96 At [14].

97 Merkin and Nicoll, above n 4, at 517-519.

98 At 519.

99 At 519

100 Robert Merkin "Supreme Court Refuses to Apply Doctrine of Merger to Damage" (2 September 2014) DLA Piper <www.dlapiper.co.nz>.

101 Michalik and Boys, above n 12, at 5.19. 
effect of a legal test. In contrast, the clear unavailability of the doctrine in non-marine insurance following Ridgecrest limits the scope of the principle outside of marine insurance.

\section{Current Relevance of the Principle}

There are two substantive points made by the Supreme Court that appear to derive directly from the indemnity principle and suggest its future scope (other than its acknowledgement that indemnity is a core principle of insurance). These are two of the three limitations on Ridgecrest's claim: no double counting and no recovery exceeding the replacement cost of the building. A substantial part of the Ridgecrest decision is dedicated to considering the principle's application, which is itself an acknowledgement of the principle's relevance. The consideration given to the principle by academics and in numerous other cases is further evidence that the principle of indemnity is certainly much more than mere business practice.

The Ridgecrest and Skyward approach is more focused on policy wording than public policy in comparison to previous (especially historical) case law, with the courts seemingly content to describe the principle as awkward in respect of replacement cost insurance. This further supports an argument that the principle is not as vital to insurance contracts as was suggested in Castellain v Preston. "Awkward" can be read as another way of saying the principle is subordinate to the focus in ordinary contract law on contractual intention. Michalik and Boys have also come to this conclusion, interpreting the approach in Skyward as an illustration of how "courts have been alive to the primacy to be given to the insurer's policy promises as overriding any understanding that insurance in general gives only an indemnity". ${ }^{102}$

It is submitted that most of the reasoning and the overall outcome indicate that the principle's influence is strictly limited by the wording of an insurance policy. In this sense, the principle, being less based on achieving its original purposes and directed more at not frustrating the intentions of the parties, is certainly more akin to a presumption of contractual intention rather than an overarching policy-based principle. This may be desirable; a presumed intention approach allows greater freedom of contract and can better meet the desires of the parties on a case-by-case basis. This approach would imply that although in Ridgecrest and $Q B E$ Insurance the insurers' liability was limited by the replacement value of the building, an insured may still recover for notional loss rather than actual loss in indemnity insurance, if the policy so provides.

\section{$D$ Where to from Here?}

It is submitted that a new conception of the principle following Ridgecrest is likely to be mostly revelatory rather than revolutionary. While the principle was once deemed a fundamental one and is still referred to as such, this has not in the past prevented the courts from allowing flexibility for agreed value policies and new-for-old provisions. The Canterbury earthquakes presented some novel 
cases in property insurance where successive losses were not repaired before further or total loss, creating results that appear at odds with the principle in some respects. But it does not necessarily follow that these decisions that seemingly subvert the principle are creating sudden, new change. While older case law like Castellain v Preston and Godin v London Assurance Co seems to make the position very clear and base the principle strongly on underlying rationales, the principle has already become somewhat superfluous in relation to these purposes, as discussed above.

This does not mean that the principle lacks relevance. The judgment in Ridgecrest illustrates that a result obviously unintended by either party (such as an insured realising a profit from a policy) is to be avoided. The indemnity principle still offers an attractive method for parties to utilise in the assessment of loss after an event, one that aids in understanding the meaning of loss and limits the liability of the insurer. It is likely that in most cases it will be very obvious that neither party intended a result at odds with the principle. In essence the principle simply becomes a self-fulfilling prophecy: it applies because parties intend it to apply.

Replacement value insurance, agreed value policies, the requirements of IPSA and the decision in Ridgecrest all show that parties are perfectly capable of agreeing to distribute risk according to their own preference and to contract out of the principle. Perhaps what is needed now is to recognise that the principle provides a set of rules that one may contract into, although it will presumably still apply in cases of any ambiguity. It is possible that the decisions in Ridgecrest, Skyward, and QBE Insurance, in making this change in approach more evident, will precipitate such recognition, and inspire more express acknowledgement of the principle in insurance contracts. In other words, the Ridgecrest and Skyward decisions will both reflect and instigate changes in thinking; yet another self-fulfilling prophecy.

In terms of addressing any new issues of moral hazard that may arise from a principle of indemnity that is focused more on presumed intention, it seems reasonable to assume that where a profit is contemplated or at least possible, insurers will have the foresight to include provisions to mitigate their risk (and indeed they are required to address such issues under IPSA). The Canterbury earthquakes provided examples of new challenges for insurers to deal with, whether it be successive losses followed by total loss before repairs could be completed, or unexpected costs involved in replacing a building under a new-for-old policy. Insurers have already begun to address these risks. For example, insurers now offer sum insured replacement policies in property insurance instead of open-ended policies. ${ }^{103}$ A principle that is not applied as uniformly as once thought is a consideration insurers can take into account when writing insurance policies.

Another possibility, however, is a potential return to treating the principle in a broad policy sense as a reaction to what may be seen by some as an undesirable direction for the law. As discussed, one

103 Zane Kennedy "Understanding insurance cover in the New Zealand Property Insurance Sector" (4 December 2014) Minter Ellison Rudd Watts <www.minterellison.co.nz>. 
expert in conjunction with a major insurance law firm, has already taken the approach that the case ought to be confined to the specific and unusual wording of the policy at issue. ${ }^{104} \mathrm{~A}$ broad policybased presumption approach is still a workable interpretation following Ridgecrest and Skyward. It still allows room for acknowledgement of the terms of the policy, where those terms are sufficiently clear to displace the presumption the principle applies.

The willingness of the courts, insurers and insureds to adapt where required suggests the change may be a more permanent one. An example of this willingness to adapt is the widespread use of replacement policies in New Zealand prior to 2010. Indemnity value simply does not always adequately address the needs and desires of an insured. Insurers have adapted to meet market demand, and addressed any increased risk accordingly (both through mechanisms to reduce moral hazard and the more recent adoption of sum insured policies). Surely recognition of a new conception of the principle is appropriate in a modern context, rather than clinging to strict principles developed hundreds of years ago in a different commercial environment. On a final note, whether the principle is based on policy or presumed intention, its status must be made clear to contracting parties. Greater certainty is desirable as it provides parties with the ability to better manage their risk.

\section{CONCLUSION}

Phrases such as "indemnity is 'fundamental' to insurance", or "one cannot receive more than a full indemnity", are often repeated - perhaps at risk of sounding hollow - without clarification of their true impact on interpretation of insurance policies.

In Ridgecrest and Skyward, the purposes underlying the principle were not as important as the wording of the policy itself, and indeed some of those underlying purposes can now be achieved through other methods, if they are not almost obsolete already. The approach taken towards the principle by the Supreme Court suggests it is in fact not a contentious matter for parties to contract out of the principle if they so desire. An understanding that the principle is contractual in origin necessitates that the contractual intention of the parties will take priority over any notion of a general indemnity principle. The principle is still relevant under this presumption of intention approach; it will apply where the policy does not contradict it and in cases of ambiguity. It is important that this is made clear to insurers and insureds alike, that they may be fully informed when contracting. 
(2016) 47 VUWLR 